\title{
Analysis of Biodegradation of Bioplastics Made of Cassava Starch
}

\author{
Nanang Eko Wahyuningtiyas ${ }^{1, *}$, Heru Suryanto ${ }^{1}$ \\ ${ }^{1}$ Department of Mechanical Engineering, Faculty of Engineering, Universitas Negeri Malang \\ Corresponding author: *nanang_tbk@yahoo.com
}

\begin{abstract}
Environmental pollution due to plastic waste taking too long to decompose has become a global problem. There have been numerous solutions proposed, one of which is the use of bioplastics. The use of cassava starch as the main ingredient in the manufacture of bioplastics shows great potential, since Indonesia has a diverse range of starch-producing plants. The aim of the present study is to analyse the effect of glycerol on microbial degradation. This experimental research investigated the use of cassava flour mixed with glycerol plasticizer at various concentrations $(0,2,2.5,3 \%)$ in the synthesis of bioplastics. The aspects studied were biodegradability, moisture absorption (using ASTM D 570), shelf life, and morphological properties (using a camera equipped with a macro lens) and SEM. This study revealed that complete degradation could be achieved on the 9th day. The addition of a large concentration of glycerol would accelerate the microbial degradation process, increase moisture, and extend the shelf life of bioplastics in a dry place.

Copyright (C) 2017Journal of Mechanical Engineering Science and Technology All rights reserved

Keywords: Bioplastics, Cassava starch, Glycerol, Degradation, Microorganism
\end{abstract}

\section{Introduction.}

Plastic waste has become a worldwide problem. Indonesia is the world's second-largest contributor of plastic waste after China [1], since it produces approximately 100 million tons of plastic for various industrial sectors [2]. According to the most recent data provided by INAPLAST (Indonesian Oleafin Aromatic Plastic Industry Asociation), the annual consumption of plastics in Indonesia was 4.7 million tons in 2015, rose to 5 million tons in 2016 [3], and is predicted to hit 9.52 million tons in 2019 [4]. One remedy to overcome the problem of plastic waste is by creating an environmentally friendly alternative to conventional plastics, i.e. bioplastics (biodegradable plastics). The use of non-biodegradable plastics and biodegradable plastics has been calculated to be $69.1 \%$ and $39.1 \%$ respectively [5]. Bioplastics are biodegradable plastics which can be degraded by microorganisms from plant-derived compounds, such as starch, cellulose, and lignin [6]. Biodegradable plastics have the same functional quality like conventional plastics, but they can be decomposed by the action of microorganisms, which produces water $(\mathrm{H} 2 \mathrm{O})$, carbon dioxide $(\mathrm{CO} 2)$, and methane (CH4) [7]. In other words, they can return back to nature after its use because it can be broken down in the environment, hence eco-friendly plastics [8]. Conventional plastics take 50 years to decompose in nature, while bioplastics can be degraded 10 to 20 times faster [9]. Starch is a natural polymer extracted from plants and can be used to produce biodegradable plastics due to its eco-friendliness, abundance, and low cost [10]-[12]. Cassava contains a large amount of starch, which can be suitably used for the production of bioplastics. This potential is a great opportunity to add value to cassava as the raw material in the manufacture of eco-friendly plastics [13]. In fact, cassava holds huge potential for the production of bioplastics since Indonesia is the third-largest producer of cassava in the world [14]. Nonetheless, there has been a lack of attention and appropriate treatment towards it, and indeed further exploration should take place. Thus, this paper takes a closer look at the degradation of bioplastics composed from cassava starch added with glycerol as a plasticiser. 


\section{Method}

\section{A. Synthesis of Bioplastics}

A 5\% cassava starch (b/v) was added to each of four different amounts of distilled water/aquades $(98.5,98,97.5$, and $97 \mathrm{ml})$, then the solutions were stirred using a magnetic stirrer for 5 minutes at $900 \mathrm{rpm}$. Next, glycerol at various concentrations, i.e. $1.5 \%, 2 \%, 2.5 \%, 3 \%(\mathrm{v} / \mathrm{v})$, was added to each solution, and then the solutions were stirred again for 5 minutes at $900 \mathrm{rpm}$. The solutions were heated in a magnetic stirer at a temperature of $\pm 80^{\circ} \mathrm{C}$, while being stirred with a magnetic stirrer for \pm 45 minutes at $900 \mathrm{rpm}$. Each stirred solution was poured into a mould with a diameter of 88 $\mathrm{mm}$, then dried in an oven with a temperature of $50^{\circ} \mathrm{C}$ for 24 hours, and finally placed at room temperature $\left(27^{\circ} \mathrm{C}-30^{\circ} \mathrm{C}\right)$ until dried.

\section{B. Observation of Morphological Properties of Bioplastics}

The surface morphology of bioplastics was observed using an electron microscope, FEI Inspect S50. Scanning Electron Microscope (SEM) was used to observe the surface of specimens (bioplastics). Before being observed, the specimens were coated with a 10-nm-thick gold.

\section{Moisture Absorption}

The moisture absorption test identified the ability of bioplastics to absorb water $(\mathrm{H} 2 \mathrm{O})$ as determined by standard ASTM D 570. Bioplastics, which had been previously dried for 24 hours in an oven at $50^{\circ} \mathrm{C}$, cooled in a desiccator, and weighed, were cut into $10 \mathrm{~mm} \times 10 \mathrm{~mm}$. The moisture absorption data of bioplastics was obtained by soaking them in water for 24 hours. After that, the bioplastics were dried with a cloth and immediately weighed. The water absorption capacity of bioplastics can be calculated as follows [17].

$$
\text { Moisture Content }(\%)=\frac{(\text { Post-Bake Weight })-(\text { Initial Weight })}{\text { Initial Weight }} \times 100
$$

\section{Biodegradability}

Biodegradable behaviour of bioplastics was determined using soil burial degradation test, i.e. bioplastics were buried in the soil, so that it would be degraded completely [18]-[20]. Degradation testing serves to determine the extent of damage of bioplastics. The damage can be seen from the mass reduction of respective specimens buried in the ground.

Bioplastics were cut into $10 \mathrm{~mm} \times 10 \mathrm{~mm}$. Then, they were buried into the ground at $8-\mathrm{cm}$ depth; the burial duration varied (3, 6, 9, and 12 days). Prior to burial, the initial mass (mass before degradation) was determined. The final mass (mass after degradation) of the bioplastics was measured afterwards. Any changes in mechanical properties due to degradation process were observed and when the bioplastics were completely degraded, the biodegradability was measured [21].

$$
\text { Microbial Resistance }(\%)=\frac{\text { Final mass }- \text { Initial mass }}{\text { Initial mass }} \times 100
$$

\section{E. Shelf Life Testing}

Shelf life testing aims to determine the durability level of bioplastics as plastic packaging. The use of organic materials in manufacturing bioplastics causes low tensile strength, short shelf life (not durable), and mould damage [22]. In this study, the shelf life test was performed through observation using a camera equipped with macro lens. Bioplastics were placed in a plastic box with limited oxygen or humidity of $45-60 \% \mathrm{RH}$ to determine the damage caused by microorganisms. By doing so, the shelf life of bioplastics under certain environmental conditions could be identified. The testing process lasted for 90 days. The results were analysed through visual observation.

\section{F. Chemical Reaction of Bioplastics}

A chemical reaction aims to determine the transformation/change in the structure of molecules involved in the reaction. The chemical reaction combines elements into compounds, decomposes compounds back into elements, and transforms existing compounds into new compounds. The reaction produces chemical combinations to form larger molecules. The splitting of a molecule into two or more smaller molecules and rearrangement of atoms in molecules. 


\section{Findings and discussion.}

\section{A. Synthesis of Bioplastics}

The bioplastics produced were hard, smooth and transparent. The surface morphology of bioplastics observed with SEM is shown in Figure 1. Cassava starch consists of semi-crystalline structures because its granules are disrupted as a result adding specific heat and solvents. Then, the semi-crystalline structures will turn into amorphous forms determined to be a fragile.

\section{B. Moisture Absorption}

Figure 2 shows that changes in water absorption of bioplastics varied depending on the variations in the concentration of glycerol. The more the glycerol is, the higher the water-swelling ratio will be [23]. It is associated with hydrophilic properties of glycerol and starch [24] [25]. These properties increase the affinity between glycerol and water, hence the increase of water absorption [26]. Higher water affinity demonstrate by adsorption and desorption isotherms [25]. The fact that cassava starch contains hydroxyl $(\mathrm{OH})$, carbonyl $(\mathrm{CO})$, and ester $(\mathrm{COOH})$ indicates that the concentration of hydrophilic properties in the bioplastics is high; high concentrations of hydrophilic starch and glycerol cause faster degradation in the soil [20].
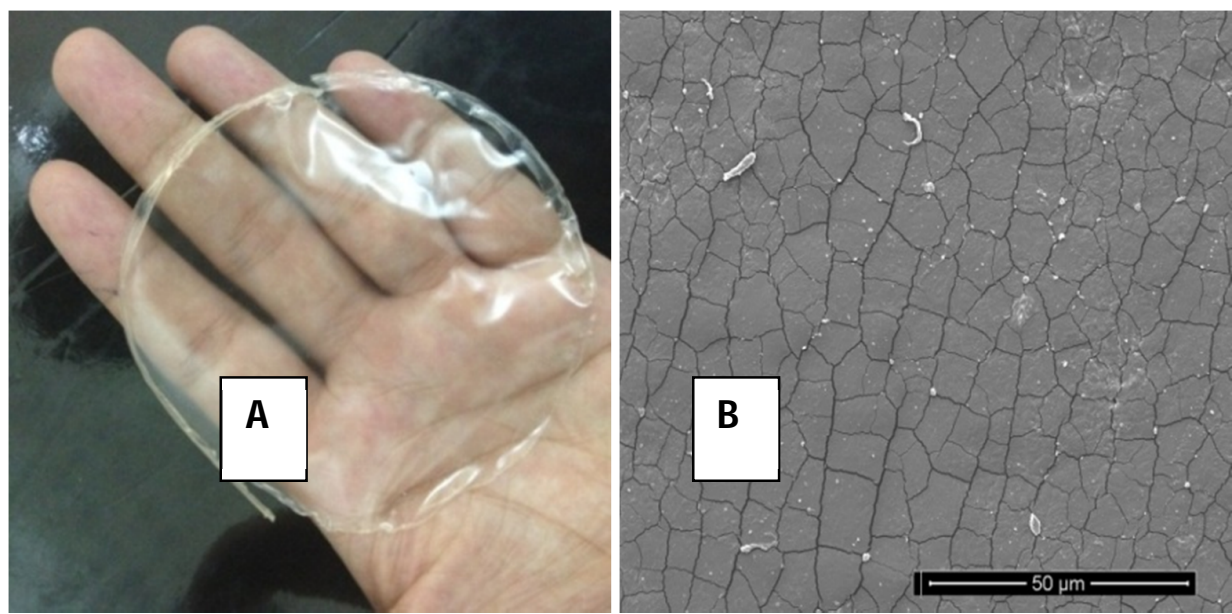

Fig. 1.Surface Morphology of Bioplastics (A), Result of Bioplastic Production (B) Result of Observation using SEM

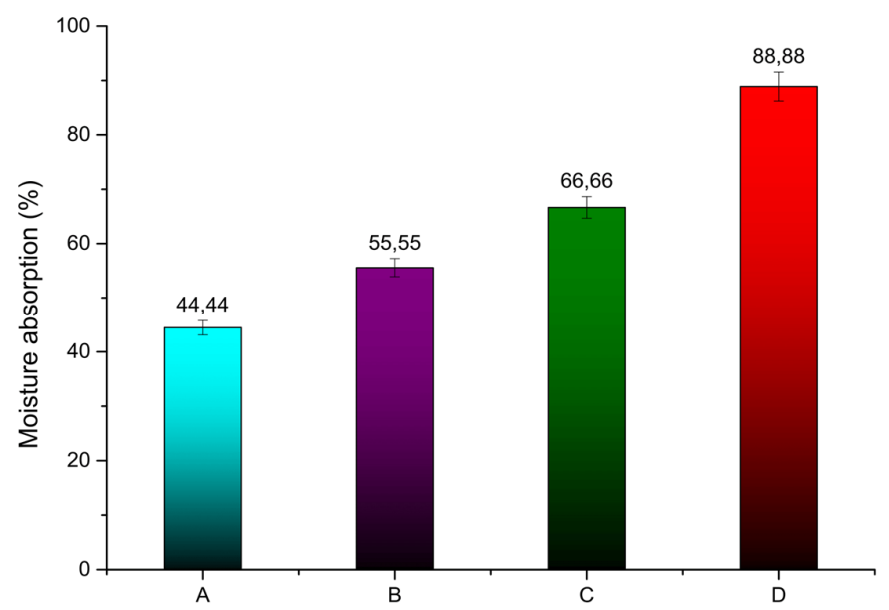

Fig. 2.Result of Moisture Absorption Testing at Various Concentrations of Glycerol (A), 1,5\% (v/v); (B), 2\% (v/v); (C), 2,5\% (v/v); and (D) 3\% (v/v) 
Table 1. Results of the Degradation of Bioplastics with various concentrations of Glycerol

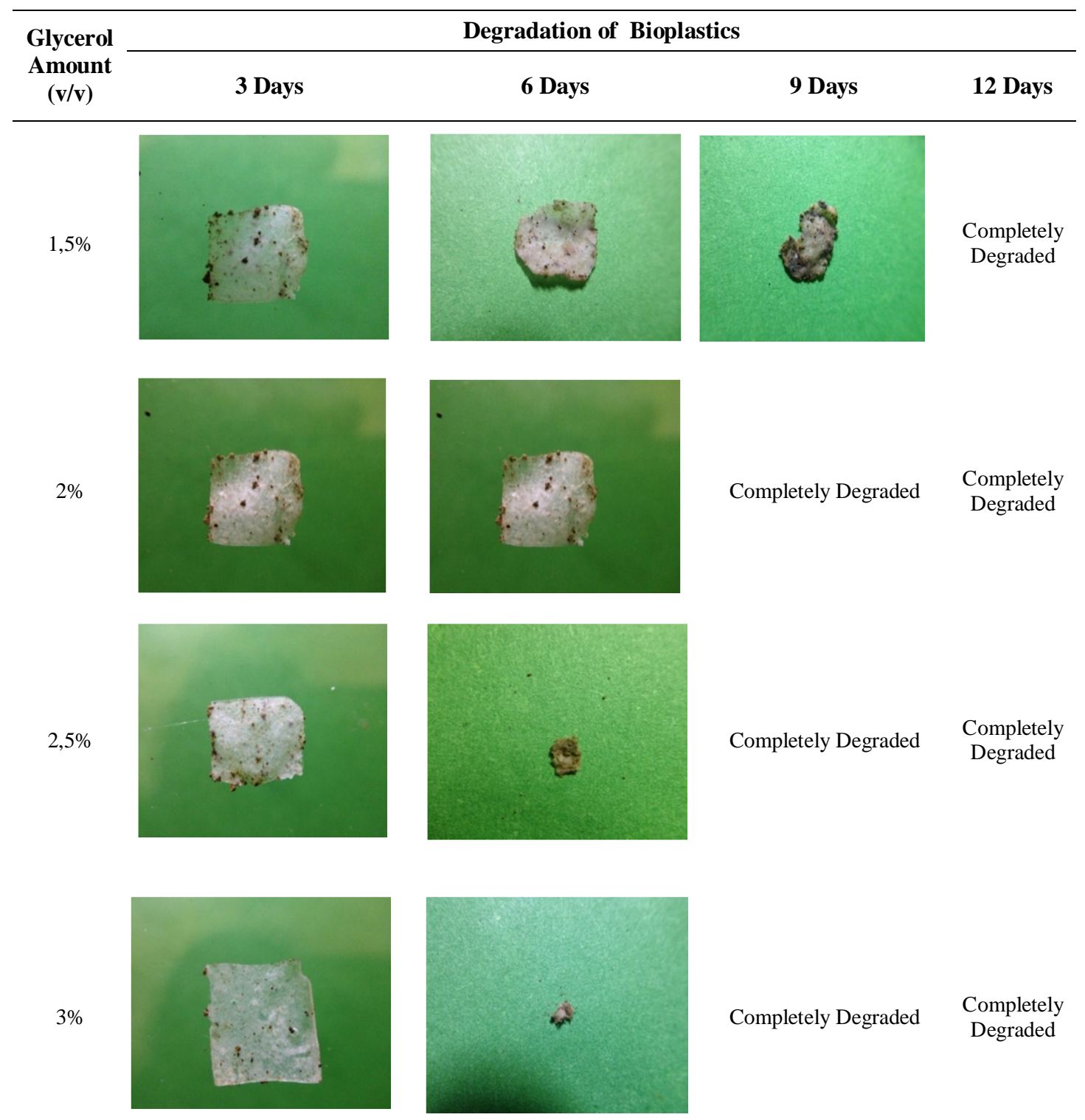

\section{Biodegradability}

Biodegradability testing was carried out to determine the degradation level of bioplastics in the environment [27] as a parameter of an environmentally friendly material [28]. Table 1 shows the mass reduction in bioplastics for 3, 6, 9, and 12 days.

The mass of bioplastics buried for 6 days was reduced by more than $50 \%$ (as shown in Figure 3). This mass loss happened because the bioplastics were composed from natural materials which were easily digested by microbes [29]. Bioplastics broke down into small pieces in 7 days, but the complete degradation occurred on the ninth day. After absorbing water from the soil, hydroxyl group in the cassava starch initiated the hydrolysis reaction; due to this reaction, cassava starch was decomposed into small pieces and quickly disappeared [30].

A high concentration of glycerol contained in bioplastics led to rapid mass reduction. The hydrophilic nature caused bioplastics to be degraded more easily [26], making bioplastics an ecofriendly packaging material. The degradation process of bioplastics was done with the help of 


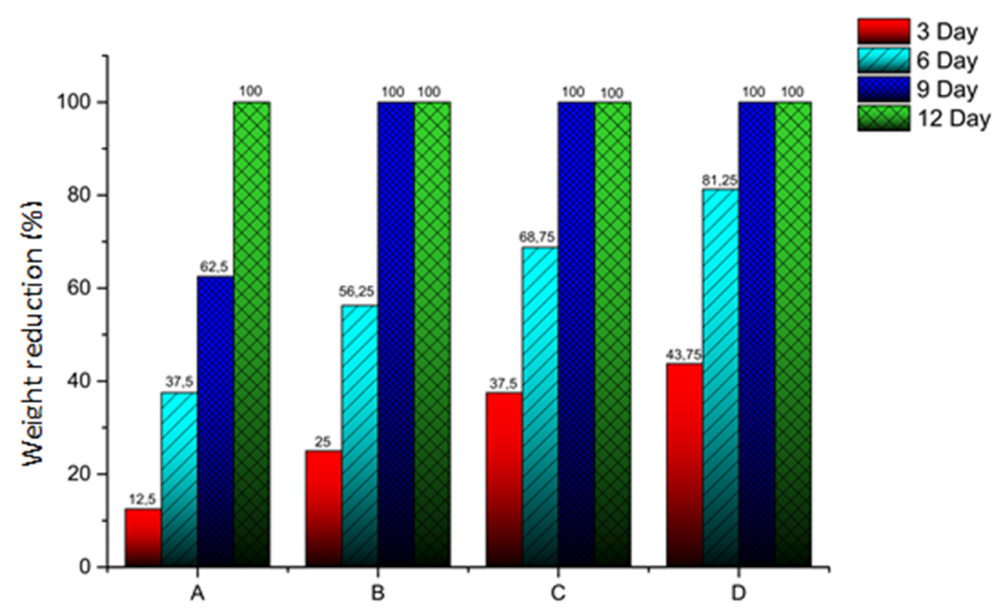

Fig. 3. Results of Bioplastics Degradation Testing with Various Amounts of Glycerol (A), 1,5\% (v/v); (B), $2 \%(\mathrm{v} / \mathrm{v}) ;(\mathrm{C}), 2,5 \%(\mathrm{v} / \mathrm{v})$; and (D) $3 \%(\mathrm{v} / \mathrm{v})$

microorganisms such as bacteria and fungi [31], mechanical degradation (wind and abrasion), and light (photo-degradation) [20].

The degradation level of a compound depends not only on the durability of the molecules, but also the $\mathrm{pH}$, temperature, humidity, and oxygen content in the environment [32] and [33]. The surrounding environment can affect $\mathrm{pH}$, redox potential, presence of suitable microorganisms, availability of adequate nutrition, and concentration of the compound [20].

Biodegradation of bioplastics can be done by several bacteria found in the soil such as Pseudomonas sp., Streptococcus sp., Staphylococcus sp., Bacillus sp., and Moraxella sp [34]. Moreover, it can be done due to the breaking of polymer chain of cassava starch containing hydroxyl $(\mathrm{OH})$ carbonyl $(\mathrm{CO})$, and also ester $(\mathrm{COOH})$ into monomer [35]. The addition of more glycerol can increase the degradation of bioplastics, since glycerol has the ability to absorb hydroxyl water [25] or absorb water easily. Water is the medium of most bacteria and microbes, particularly those in the soil. As a result, water content results in plastics becoming degraded more easily [26]. The more the amount of glycerol, the more the amount of water that can penetrate through the structure of bioplastics and assist in the biological/microbial processes [36]. The more the glycerol and the starch, the easier the degradation [26]. The degradation process then continues by expanding the surface through erosion and perforation; these methods can increase the speed of degradation because the holes formed accelerate the diffusion of oxygen and enzymes into the bioplastics [20].

\section{Shelf Life Testing}

Bioplastics made of organic cassava starch had a low level of tensile strength, making them ineffective packaging materials. The shelf life of bioplastics was quite low; it will damage food stuff being packed due to the migration of spoilage bacteria to the food. The growth of fungi in bioplastics without the addition of natural preservatives can accelerate the deterioration of food [22].

As shown in Figure 4, bioplastics have been covered with white fungi, so that the polymer chains split as a result of reducing weight, so enzymes which depolymerise the polymers it can be excreted outside the cell [37], [7]. Depolymerisation occurs because of the working process of extracellular enzymes (consisting of endo and exo enzyme). Endo enzymes break the internal bonds in the main polymer chain randomly, while exo enzymes break the monomer unit in the main chain sequentially [38].

The fungal growth in bioplastics caused by fungi from glycerol as a plasticiser, i.e. Aspergillus niger, A. versicolor, Cladosporium sp., Fusarium sp., Penicillium sp., Trichoderma sp., and Verticillium sp [39] and [40] is influenced by environment, catabolism of bioplastics, and temperature [33] and [22]. The storage temperature can affect the activity of microbes and fungi. Generally, storage temperature can accelerate the migration of additives in bioplastics [41]. 

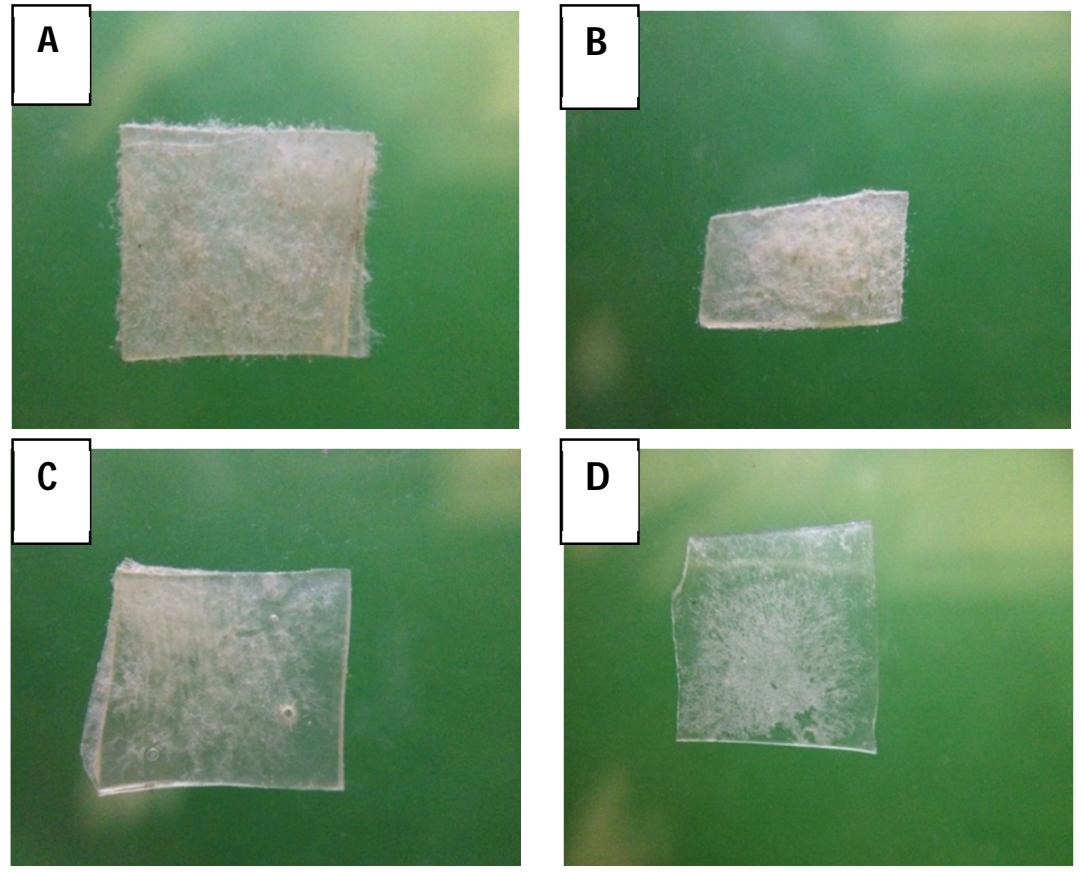

Fig. 4. Shelf Life Testing for 90 Days with Various Concentrations of Glycerol (A), 1,5\% (v/v); (B), 2\% $(\mathrm{v} / \mathrm{v}) ;(\mathrm{C}), 2,5 \%(\mathrm{v} / \mathrm{v})$; and $(\mathrm{D}) 3 \%(\mathrm{v} / \mathrm{v})$

A high concentration of glycerol serves as an anti-fungal for bioplastics, hence an increased shelf life. Anti-fungal ingredients in bioplastic can control the growth of fungi and extend the shelf life [41]. The use of natural anti-fungal substances is likely to increase, as consumers are getting more aware of their health and potential dangers of synthetic preservatives [42] and [43]. The advantage of adding additives or anti-fungal agents into bioplastics is to increase the shelf life. In addition, glycerol layers reinforced with anti-fungal components can inhibit bacterial spoilage and reduce health risks [43].

\section{Conclusions}

The degradation of bioplastics is affected by water content, moisture, and oxygen level. Resistance to degradation of bioplastics made of cassava starch was strongly influenced by the amount of glycerol used as the plasticiser. The greater the amount of glycerol was used, the faster the degradation process (the complete degradation occurred on the $9^{\text {th }}$ day), the higher the moisture absorption, and the longer the shelf life (in a dry place) would be.

\section{References}

[1] J. R. Jambeck, R. Geyer, C. Wilcox, T. R. Siegler, M. Perryman, A. Andrady, R. Narayan, and K. Lavender, "Plastic waste inputs from land into the ocean," Science (80 )., vol. 347, no. 6223, pp. 768770, 2015.

[2] LIPI, "Bahan Plastik Ramah Lingkungan - Pusat Penelitian Bioteknologi-LIPI," Bahan Ramah lingkungan, 2007.

[3] H. Suryanto, P. T. Hutomo, R. Wanjaya, and P. Puspitasari, "The Stucture of Bioplastic from Cassava Starch with Nanoclay Reinforcement," AIP Int. Proceding Int. Mech. Eng. Eng. Educ., vol. 30027, pp. $1-4,2016$.

[4] [CNN, "Indonesia Penyumbang Sampah Plastik Terbesar Kedua Dunia,” 2016.

[5] European Bioplastic, "European Bioplastic," 2015.

[6] L. Averous, "Biodegradable Multiphase Systems Based on Plasticized Starch: A Review," Macromol. Sci. Part C Polym. Rev., vol. 44, no. 3, pp. 231-274, 2004.

[7] V. G. L. Souza and F. A. Luisa, "Nanoparticles in food packaging: Biodegradability and potential migration to food-A review," Food Packag. Shelf Life, vol. 8, pp. 63-70, 2016.

[8] J. M. Sakra, "Biodegradable Pati Kentang Sebagai Bahan Plastik," Jaringan Penelitian KTI, 2015. 
[9] M. I. Kartika, “Pati, Bahan Dasar untuk Membuat Plastik,” Kompas, 2012.

[10]S. Domenek, P. Feuilloley, J. Gratraud, H. Morel Marie, and S. Guilbert, "Biodegradability of wheat gluten based bioplastics," Chemosphere, vol. 54, no. 4, pp. 551-559, 2004.

[11]Y. Song and Q. Zheng, "Preparation and properties of thermo-molded bioplastics of glutenin-rich fraction," Cereal Sci., vol. 48, no. 1, pp. 77-82, 2008.

[12] G. J. Gutierrez, P. Partal, M. G. M., and C. Gallegos, "Effect of processing on the viscoelastic, tensile and optical properties of albumen/starch-based bioplastics," Carbohydr. Polym., vol. 84, no. 1, pp. 308$315,2011$.

[13]F. Firdaus and A. Chairil, "Potensi Limbah Padat-cair Industri Tepung Tapioka sebagai Bahan Baku Film Plastik Biodegradabel," Logika, vol. 1, no. 2, pp. 38-44, 2004.

[14] Suharyo, “Tiga Negara Asia Berpotensi Jadi Tujuan Ekspor Singkong,” Tempo, 2011.

[15]H. Suryanto, N. E. Wahyuningtiyas, Wanjaya Reza, Puspitasari Poppy, and Sukarni, "Struktur dan Kekerasan Bioplastik dari Pati Singkong," in Prosiding SeNTerTek (Seminar Nasional Terapan Teknologi) Politeknik Negeri Malang, 2016.

[16] ASTM D 570, Standard Test Method for Water Absorption of Plastics. 2004.

[17]P. Kampeerapappun, D. Aht-ong, D. Pentrakoon, and K. Srikulkit, "Preparation of cassava starch/montmorillonite composite film," Carbohydr. Polym., vol. 67, no. 2, pp. 155-163, 2007.

[18]C. R. Di Franco, V. P. Cyras, J. P. Busalmen, R. A. Ruseckaite, and A. Vázquez, "Degradation of polycaprolactone/starch blends and composites with sisal fibre," Polym. Degrad. Stab., vol. 86, no. 1, pp. 95-103, 2004.

[19]R. Ardiansyah, "Pemanfaatan Pati Umbi Garut Untuk Pembuatan Plastik Biodegradable," Indonesia, 2011.

[20]A. U. Nathiqoh, "Uji Ketahanan Biodegradable Plastic Berbasis Tepung Biji Durian (Durio Zibethinus Murr) Terhadap Air Dan Pengukuran Densitasnya,” Indonesia, 2013.

[21] Syaubari, Riza Medyan, Wani Nelly, and Abidah Nur, "Sintesis Plastik Biodegradable Dari Pati Tapioka Dan Kitosan Dengan Rbdpo (Refined Bleached Deodorized Palm Oil) Sebagai Pemlastis," in Seminar Nasional Kimia dan Pendidikan V, 2013, no. April, pp. 1-7.

[22]N. F. Nahwi, “Analisis Pengaruh Penambahan Plastisizer Gliserol Pada Karakteristik Edible Film dari Pati Kulit Pisang Raja, Tongkol Jagung dan Bonggol Enceng Gondok,” Indonesia, 2016.

[23] S. Wafiroh, T. Ardiarto, and E. T. Agustin, "Pembuatan dan Karakterisasi Edible Film dari Komposit Kitosanpati Garut (Maranta Arundinaceae L) dengan Pemlastis Asam Laurat," J. Math. Sci., vol. 13, no. $1,2010$.

[24] G. Junjie and M. A. Hanna, "Functional properties of extruded foam composites of starch acetate and corn cob fiber," Ind. Crops Prod., vol. 19, no. 3, pp. 255-269, 2004.

[25] J. Bonilla, Vicentini M, Dos Rodolfo M C, Bittante Q B, and Sobral Paulo J A, "Mechanical properties of cassava starch films as affected by different plasticizers and different relative humidity conditions," Int. J. Food Stud., vol. 4, no. April, pp. 116-125, 2015.

[26]A. Septiosari, Latifah, and Kusumastuti Ella, "Pembuatan Dan Karakterisasi Biopl Astik Limbah Biji Mangga Dengan Penambahan Selulosa Dan Gliserol,” Chem. Sci., vol. 3, no. 2252, pp. 1-6, 2014.

[27]R. Harnist and Y. Darni, "Penentuan Kondisi Optimum Konsentrasi Plasticizer Pada Sintesa Plastik Biodegradable Berbahan Dasar Pati Sorgum," in Seminar Nasional Sains dan Teknologi, 2011.

[28]L. I. Yuniarti, G. S. Hutomo, and R. Abdul, "Karakterisasi dan Bioplastik Berbasis Pati Sagu (Metroxylon SP)," Argotekbis, vol. 2, no. 1, pp. 38-46, 2014.

[29] Y. D. Hartatik, L. Nuriyah, and Iswarin, "Pengaruh Komposisi Kitosan terhadap Sifat Mekanik dan Biodegradable Bioplastik," p. 4, 2014.

[30]L. S. Kyong, Seong Dong Gi, and Youn Jae Ryoun, "Degradation and rheological properties of biodegradable nanocomposites prepared by melt intercalation method," Fibers Polym., vol. 6, no. 4, pp. 289-296, 2005.

[31]N. Lucas, C. Bienaime, C. Belloy, M. Queneudec, Silvestre Françoise, and Nava-Saucedo José Edmundo, "Polymer biodegradation: Mechanisms and estimation techniques - A review," Chemosphere, vol. 73, no. 4, pp. 429-442, 2008.

[32] Massardier-Nageotte V., Pestre C., T. Cruard-Pradet, and Bayard R., "Aerobic and anaerobic biodegradability of polymer films and physico-chemical characterization," Polym. Degrad. Stab., vol. 91, no. 3, pp. 620-627, 2006. 
[33]S. M. Emadian, T. T. Onay, and B. Demirel, "Biodegradation of bioplastics in natural environments," Waste Manag., 2016.

[34] Maran J. Prakash, Sivakumar V., Thirugnanasambandham K., and Sridhar R., "Degradation behavior of biocomposites based on cassava starch buried under indoor soil conditions," Carbohydr. Polym., vol. 101, no. 1, pp. 20-28, 2014.

[35]I. G. Sanjaya and T. Puspita, "Pada Karakteristik Plastik Biodegradable Dari Pati Limbah Kulit Singkong," Pengelolahan Limbah, no. 2305100060, 2012.

[36] G. Wypych, Plasticizers Use and Selection for Specific Polymers. Canada, 2004.

[37] Mueller Rolf-Joacjim, "Biological degradation of synthetic polyesters-Enzymes as potential catalysts for polyester recycling," Process Biochem., vol. 41, no. 10, pp. 2124-2128, 2006.

[38] Marbun Eldo Sularto, “Universitas Indonesia Sintesis Bioplastik Dari Pati Ubi Jalar,” Indonesia, 2012.

[39]J. Szumigaj, Z. Zakowska, L. Klimek, Rosicka-Kaczmarek J., and Bartkowiak A., "Assessment of polylactide foil degradation as a result of filamentous fungi activity," Polish J. Environ. Stud., vol. 17, no. 3, pp. 335-341, 2008.

[40]E. B. Sihaloho, "Evaluasi Biodegradabilitas Plastik Berbahan Dasar Campuran Pati dan Polietilen Menggunakan Metode Enzimatik, Konsorsia Mikroba dan Pengomposan,” Indonesia, 2011.

[41] Quintavalla Stefania and Loredana Vicini, "Antimicrobial food packaging in meat industry," Meat Sci., vol. 62, no. 3, pp. 373-380, 2002.

[42]P. Suppakul, Miltz J., Sonneveld K., and Bigger S.W., "Active Packaging Technologies with an Emphasis on Antimicrobial Packaging and its Applications," J. Food Sci., vol. 68, no. 2, pp. 408-420, 2003.

[43]C. Winarti, Miskiyah, and Widananingrum, "Teknologi Produksi dan Aplikasi Pengemas Edible Antimikroba Berbasis Pati," J. Litbang Pertan., vol. 31, no. 3, pp. 85-93, 2012. 